\title{
Frequency of CCR5 $\Delta 32$ Mutation in Human Immunodeficiency Virus (HIV)-seropositive and HIV- exposed Seronegative Individuals and in General Population of Medellin, Colombia
}

\author{
Francisco J Díaz, Jorge A Vega, Pablo J Patiño*, Gabriel Bedoya, \\ Jorge Nagles**, Cecilia Villegas ${ }^{* *}$, Rodrigo Vesga***, Maria T Rugeles ${ }^{+}$
}

Laboratorio de Virología *Laboratorio de Inmunología, Departamento de Microbiología y Parasitología, Facultad de Medicina, Universidad de Antioquia, AA 1226, Medellin, Colombia **Instituto de los Seguros Sociales,

Medellin, Colombia ***Instituto Metropolitano de Salud, Medellin, Colombia

Repeated exposure to human immunodeficiency virus $(H I V)$ does not always result in seroconversion. Modifications in coreceptors for HIV entrance to target cells are one of the factors that block the infection. We studied the frequency of $\Delta 32$ mutation in ccr5 gene in Medellin, Colombia. Two hundred and eighteen individuals distributed in three different groups were analyzed for $\Delta 32$ mutation in ccr 5 gene by polymerase chain reaction (PCR): 29 HIV seropositive (SP), 39 exposed seronegative (ESN) and 150 individuals as a general population sample (GPS). The frequency of the $\Delta 32$ mutant allele was $3.8 \%$ for

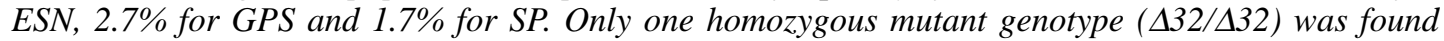
among the ESN (2.6\%). The heterozygous genotype (ccr5/A32) was found in eight GPS (5.3\%), in one $S P(3.4 \%)$ and in one ESN (2.6\%). The differences in the allelic and genotypic frequencies among the three groups were not statistically significant. A comparison between the expected and the observed genotypic frequencies showed that these frequencies were significantly different for the ESN group,

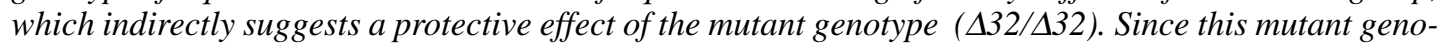
type explained the resistance of infection in only one of our ESN persons, different mechanisms of protection must be playing a more important role in this population.

Key words: CCR5 - $\Delta 32$ mutation - human immunodeficiency virus (HIV) infection - exposed seronegative

Since the beginning of the acquired immunodeficiency syndrome (Aids) epidemic, it was determined that sexual activity with multiple partners was the main risk factor to acquire human immunodeficiency virus (HIV) infection with the subsequent development of Aids. However, there is strong evidence suggesting a natural resistance to infection in several individuals who have remained uninfected despite the fact that they have had several expositions to HIV, particularly through sexual intercourse (Paxton et al. 1996). The biological basis for this resistance is just starting to be understood.

To enter the target cell the HIV requires the presence of the CD4 molecule that acts as receptor and of a second molecule or coreceptor, that in the

\footnotetext{
This work received financial support from the University of Antioquia and Banco de la Republica.

${ }^{+}$Corresponding author. Fax: + 57-4 510 6062. E-mail: mtrugel@catios.udea.edu.co

Received 26 August 1999

Accepted 4 January 2000
}

majority of cases is a chemokine receptor (Deng et al. 1996, Feng et al. 1996). Among the chemokine receptors, CCR5 and CXCR4 are the main coreceptors for HIV entrance.

Almost simultaneously with the finding of HIV coreceptors, a mutation in the gene that codifies for the CCR5 molecule was described, which confers a high degree of resistance to HIV infection in vitro and in vivo (Paxton et al. 1996, Liu et al. 1996). This mutation named $\Delta 32$ consists in a 32 base-pair deletion that encodes for a non-functional protein, and as a result it is not expressed in the cell membrane. Homozygous individuals for this mutation do not have any known immunologic or biologic alteration (Liu et al. 1996).

The $\Delta 32$ allele is present mainly in Caucasian population (Liu et al. 1996, Martinson et al. 1997, Magierowska et al. 1998). In United States the frequency is $8 \%$ to $10 \%$ in white population but less than $1 \%$ in Afro-American individuals. There is also a very low frequency of the mutation among Caucasians in Asia (Pakistan and India) and it has not been reported in China, Japan or pure African population (Martinson et al. 1997). In Latin America the frequencies have been barely stud- 
ied. It was not detected among 32 individuals from Venezuela nor in Amerindian groups (Liu et al. 1996, Martinson et al. 1997). In Colombia there are no reports addressing this issue.

In sexually exposed to HIV but seronegative individuals (ESN), the frequency of $\Delta 32 / \Delta 32$ genotype reaches $2.8 \%$ to $3.6 \%$, which corresponds to two to three times the frequency found in Caucasian non-exposed population (Dean et al. 1996, Huang et al. 1996). This frequency can go up to $33 \%$ in persons with higher risk of infection (Huang et al. 1996). In contrast, HIV infected individuals exhibit the lower frequency of $\Delta 32$ allele. It was considered that individuals with homozygous mutant genotype $(\Delta 32 / \Delta 32)$ were $100 \%$ resistant to HIV infection, at least with M-tropic strains, that uses CCR5 molecule as coreceptor. However, recently there were reports of HIV infection in two individuals who are homozygous for the mutant allele $(\Delta 32 / \Delta 32)$ (Biti et al. 1997). These infections could have occurred with T-tropic strains that use the CXCR4 molecule as coreceptor to enter the target cells.

It has been difficult to establish if the genotype $\mathrm{ccr} 5 / \Delta 32$ confers any degree of resistance to infection. The studies on this aspect are contradictory (Samson et al. 1996, Dean et al. 1996, Huang et al. 1996, Hoffman et al. 1997).

From the literature one can conclude that $\Delta 32 /$ $\Delta 32$ genotype confers a high degree of protection to HIV infection, but it is not the main factor associated to resistance, since the majority of ESN lack this genetic factor. Different mechanisms such as other coreceptor mutations or immunological factors could account for the lack of infections in this high-risk group.

This study was carried out to estimate the frequency of $\Delta 32$ allele and the genotypes for the ccr5 gene in different subgroups: ESN, seropositive and general population in order to explore the influence of this genetic factor in the behavior of HIV infection in our country.

\section{MATERIALS AND METHODS}

Population -The study was carried out in three groups of individuals. ESN: persons with history of repeated sexual intercourse without protection with HIV infected subjects. The number of subjects in this group is close to the universe of known ESN in our city; SP: all the persons included in this group were sexual partners of ESNs who had antibodies anti-HIV and some of them also presented clinical signs of HIV infection; GPS: this population were adult volunteers, most of them students and workers from our institution or health institutions related to our university. None of them were selected based on risk for HIV infection. The
HIV serological status for persons in this group was not determined.

Serological status - The serological status for individuals in the ESN group was confirmed by an ELISA test (Enzygnost HIV-1+2 Plus, Behring Diagnostics, Margurg, Germany).

Genotype determination - The genotype determination was carried out as previously described (Michael et al. 1997). Briefly, peripheral blood sample was collected with EDTA as anticoagulant. Mononuclear cells were separated by FicollHypaque gradient. Part of the cells was cryopreserved for future functional studies. The remaining cells were used for DNA extraction using the phenol-chloroform technique. The specific segment of ccr5 gene was amplified by polymerase chain reaction (PCR) using the following primers: CCR5 $\Delta 1$ (5'-ACCAGATCTCAAAAAGAAGGT CT-3') and CCR5 $\triangle 2$ (5'-CATGATGGTGAAG ATAAGCCTCACA-3'). The reaction contained 5 pmol of each primer, 0.3 units of Taq DNA polymerase (Perkin-Elmer), $2 \mathrm{mM}$ of $\mathrm{MgCl}_{2}$ and 200 $\mu \mathrm{M}$ of each dNTP in a final volume of $25 \mu \mathrm{l}$. The reaction was subject to 30 cycles of amplification with three temperatures $96^{\circ} \mathrm{C}$ x $15 \mathrm{sec}, 58^{\circ} \mathrm{C}$ x 60 sec and $72^{\circ} \mathrm{C} \times 60 \mathrm{sec}$. The result of the amplification was electrophoresed in a $2 \%$ agarose gel, stained with ethidium bromide and visualized under U.V. transillumination. For wild genotype (ccr5/ ccr5) the PCR product was of $225 \mathrm{bp}$ while a product of $193 \mathrm{bp}$ indicated a mutant homozygous $(\Delta 32 /$ $\Delta 32)$. Presence of both bands indicated a heterozygous genotype (ccr5/ $\Delta 32)$ (Figure).

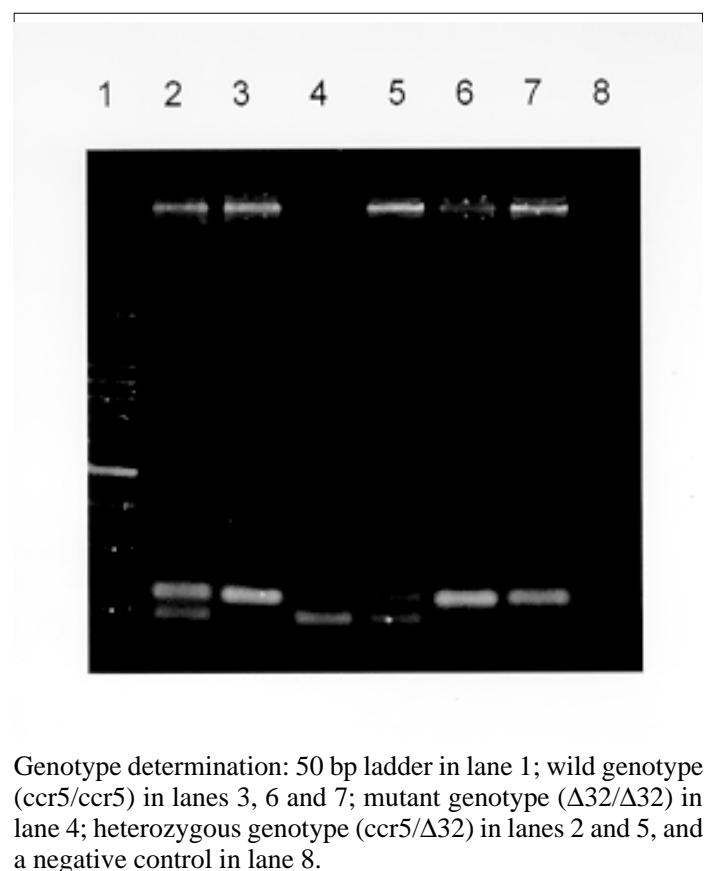
a negative control in lane 8 . 
Statistical analysis - The allelic and genotypic frequencies found were compared and the differences evaluated using the chi square test $\left(\chi^{2}\right)$. The differences between the expected and the observed frequencies of genotypes were evaluated by the same test.

\section{RESULTS}

We studied 218 individuals divided in three groups: ESN, SP and GPS. Their distribution and demographic profile is shown in Table I. All groups had a similar age average. The GPS and ESN groups had a similar distribution of gender but different to SP group in which males were predominant. The majority of couples were heterosexual and few of them were homosexual or individuals non-pared with bisexual preferences. All the seropositive subjects had acquired the infection through sexual intercourse.

The genotype frequencies are shown in Table II. The highest frequency was for the wild genotype (ccr5+/ccr5). The heterozygous genotype (ccr5+/ 432 ) was found in eight GPS, in one SP and in one ESN. Only one homozygous mutant genotype $(\Delta 32 / \Delta 32)$ was found among the ESN (Figure). The difference in the frequencies among the three groups studied was not statistically significant. The allelic frequencies for ccr5 and $\Delta 32$ are shown in Table III. The frequency of the mutant allele $\Delta 32$ was $3.8 \%$ for ESN, $2.7 \%$ for GPS and $1.7 \%$ for SP. The differences were not statistically significant.

Based on the allelic frequencies of each group is possible to predict the genotype frequency considering that they follow Hardy-Weinberg equilibrium. That means that the frequencies have a binomial distribution according to the following equation: $\mathrm{p}^{2}+2 \mathrm{pq}+\mathrm{q}^{2}=1$, where $\mathrm{p}$ and $\mathrm{q}$ are the allelic frequencies of ccr5+ and $\Delta 32$, respectively, and $\mathrm{p}^{2}, 2 \mathrm{pq}$ and $\mathrm{q}^{2}$ are the genotype frequencies of ccr5+/ccr5+, ccr5+/ $\Delta 32$ y $\Delta 32 / \Delta 32$, respectively. A comparison between the expected and the observed genotypic frequencies are shown in Table IV. In SP and GPS the observed frequencies are similar to the ones expected, while in the ESN
TABLE I

Demographic profile

\begin{tabular}{|c|c|c|c|}
\hline & GPS & SP & ESN \\
\hline No. of individuals & 150 & 29 & 39 \\
\hline Male no. $(\%)$ & $54(36)$ & $26(90)$ & $14(36)$ \\
\hline Female no. (\%) & $96(64)$ & $3(10)$ & $25(64)$ \\
\hline Media age (range) & $32(19-68)$ & $35(23-46)$ & $31(19-49)$ \\
\hline $\begin{array}{l}\text { Heterosexual }{ }^{a} \\
\text { no. }(\%)\end{array}$ & N.D. & $24(83)$ & $29(74)$ \\
\hline $\begin{array}{l}\text { Homosexual } \\
\text { no. }(\%)\end{array}$ & N.D. & $5(17)$ & $10(26)$ \\
\hline
\end{tabular}

$a$ : type of sexual relation; N.D.: not determined; GPS: general population sample; SP: seropositive; ESN: exposed seronegative.

TABLE II

Genotypic frequencies

\begin{tabular}{|c|c|c|c|}
\hline Genotype & GPS & SP & ESN \\
\hline & \multicolumn{3}{|c|}{ No. (frequency) } \\
\hline ccr5/ccr5 & $142(0.947)$ & $28(0.966)$ & $37(0.948)$ \\
\hline $\operatorname{ccr} 5 / \Delta 32$ & $8(0.053)$ & $1(0.034)$ & $1(0.026)$ \\
\hline$\Delta 32 / \Delta 32$ & $0(0.000)$ & $0(0.000)$ & $1(0.026)$ \\
\hline
\end{tabular}

GPS: general population sample; SP: seropositive; ESN: exposed seronegative.

group the observed frequency differed significantly from the expected frequency getting far away from Hardy-Weinberg equilibrium $(p<0.0005)$.

Since the number of individuals in the ESN group and the frequency of $\Delta 32$ were low, it was not possible to establish a relation between ccr5 genotype and some risk behaviors such as the frequency of the use of condom, type of sexual relation, and time of exposition. The only person with a mutant homozygous genotype was a woman who had a stable sexual relation for three years with a mean of eight non-protected sexual intercourses per month with her infected husband. The subject with heterozygous genotype found in this group corresponds to a promiscuous bisexual man who had frequently anal sexual intercourses during seven months with an infected couple.

TABLE III

Allelic frequencies

\begin{tabular}{|c|c|c|c|c|c|c|}
\hline \multirow[t]{2}{*}{ Population } & \multicolumn{2}{|c|}{ GPS } & \multicolumn{2}{|c|}{$\mathrm{SP}$} & \multicolumn{2}{|c|}{ ESN } \\
\hline & No. (frequency) & $95 \% \mathrm{CI}$ & No. (frequency) & $95 \% \mathrm{CI}$ & No. (frequency) & $95 \% \mathrm{CI}$ \\
\hline $\operatorname{ccr} 5$ & $292(0.973)$ & $0.955-0.991$ & $57(0.983)$ & $0.950-1.000$ & $75(0.962)$ & $0.919-1.000$ \\
\hline$\Delta 32$ & $8(0.027)$ & $0.009-0.045$ & $1(0.017)$ & $0.000-0.050$ & $3(0.038)$ & $0.000-0.081$ \\
\hline
\end{tabular}

95 CI\%: 95\% Confidence Interval; GPS: general population sample; SP: seropositive; ESN: exposed seronegative. 
TABLE IV

Differences between expected and observed numbers for each genotype

\begin{tabular}{|c|c|c|c|c|c|c|}
\hline \multirow[b]{2}{*}{ Genotype } & \multicolumn{2}{|c|}{ GPS } & \multicolumn{2}{|c|}{ SP } & \multicolumn{2}{|c|}{$\mathrm{ESN}$} \\
\hline & Observed & Expected & Observed & Expected & Observed & Expected \\
\hline $\operatorname{ccr} 5 / \operatorname{ccr} 5$ & 142 & 142.11 & 28 & 28.01 & 37 & 36.06 \\
\hline $\operatorname{ccr} 5 / \Delta 32$ & 8 & 7.79 & 1 & 0.97 & 1 & 2.88 \\
\hline$\Delta 32 / \Delta 32$ & 0 & 0.11 & 0 & 0.01 & 1 & 0.06 \\
\hline & \multirow{2}{*}{\multicolumn{2}{|c|}{0.113}} & \multicolumn{2}{|c|}{0.010} & \multicolumn{2}{|c|}{16.556} \\
\hline$p$ value & & n.s. & \multicolumn{2}{|c|}{ n.s. } & \multicolumn{2}{|c|}{$p<0.0005$} \\
\hline
\end{tabular}

n.s.: not significant; GPS: general population sample; SP: seropositive; ESN: exposed seronegative.

\section{DISCUSSION}

The ethnic composition of Colombian population is a product of the mixture of Europeans, Africans and native Indians. Europe contribution is mainly Spanish (Bravo et al. 1996). Two reports of $\Delta 32$ frequency in Spanish population showed an allele frequency of $8.6 \%$ (95\%CI 4.9-12.3\%) in Basques, $8.2 \%$ (95\%CI 5.4-10.9\%) in Catalans and $5 \%$ (95\% CI 2.0-8.0\%) in individuals from San Sebastian (Martinson et al. 1997, Magierowska et al. 1998).

In our study the frequency of $\Delta 32$ for the GPS group was $2.7 \%$ (95\%CI $0.90-4.5 \%)$. Based in this result we could calculate that the Spanish component of the GPS is close or even lower than $50 \%$. This estimation is different from a previous report by Bravo et al. (1996), in which using a panel of different genetic markers they observed a prevalence of the European component over the other races in the population from our province (Antioquia). Since the GPS sample not only included people born in Antioquia but residents of this province, it is possible that a significant number of individuals included in this group were born in different provinces where the influence of the European race is not known. This fact might explain the observed low prevalence of $\Delta 32$.

Although this study found a higher prevalence of $\Delta 32$ allele and $\Delta 32 / \Delta 32$ genotype among ESN, the differences in the frequencies were not significant (Tables II, III). Probably the reduced sample size did not allow to show a significant association between genotype and infection.

In the absence of positive and negative selection or other factors such as frequent recent migration, high mutational rate or high index of endogamy, the distribution of genotypes in each group must be similar to the predicted values following the Hardy-Weinberg distribution. The GPS exhibited a genotypic distribution in equilibrium. Since the circulation of HIV is a selection factor this fact could have two explanations: the frequency of pro- tective genotype $\Delta 32 / \Delta 32$ is too low to be perceptible, or the degree of exposition to HIV is still low in this population. Knowing the frequency of $\Delta 32$ allele, we calculated the frequency of the $\Delta 32$ / $\Delta 32$ genotype as 0.00071 . This means that only one person among 1406 individuals would carry the mutant homozygous genotype $(\Delta 32 / \Delta 32)$.

The distribution of genotypes in SP is also according to Hardy-Weinberg equilibrium. The explanation of this fact in this group is more difficult, since all the individuals have been sexually exposed to HIV and this must have positively selected the wild genotype ccr5+/ccr5+. It is possible that the rapid evolution to Aids and the death of individuals carrying wild genotypes over the heterozygous could compensate this effect, but again the low frequency of $\Delta 32$ allele makes the analysis difficult.

The lack of equilibrium in the genotypic frequencies among the ESN was highly significant due to the presence of one individual with the $\Delta 32$ / $\Delta 32$ genotype. This makes the frequency 17 times superior than expected (Table IV). This finding is hardly explained by one of the following arguments that may also contribute to break Hardy-Weinberg equilibrium in a population: recent European immigration and endogamy, since these facts are not frequently found among our population. The mutational rate for this mutation should not be high either. The possibility that this distribution might have occurred randomly is also very low $(p<0.0005)$. The positive selection of individuals with such genotype $\Delta 32 / \Delta 32$ among ESN is the most plausible explanation for the lack of equilibrium. Therefore, the protective effect of this genotype was shown, although indirectly.

In our study the frequency of the $\Delta 32 / \Delta 32$ genotype only explains the resistance to infection in a very low percentage of ESN individuals (2.6\%). This is concordant with other studies that have shown similar findings (Bernard et al. 1999). Since many of the individuals in the ESN group have 
had a high degree of exposition to HIV, there must be other mechanisms responsible for this "natural protection". Recently, it was demonstrated that the HIV could use other chemokine receptors such as CCR2 and CCR3 as correceptors (Berger et al. 1999). Therefore, mutations in these molecules or in the chemokine receptors ligands might explain the resistance to HIV infection of some individuals. However, the mutation CCR2-64I, was not associated with a resistant phenotype but rather with a delayed in disease progression (Smith et al. 1997). Similarly, the polimorphism SDF-1-3'A reported in the $\alpha$-chemokine SDF-1 was associated with the delayed in the onset of Aids related symptoms (Winkler et al. 1998). Other immune system genes such as those of the HLA system appear to also influence the disease progression, although the effects are complex and may depend on interactions with other host genes (McNicholl et al. 1997). Specific cellular immune responses, particularly mediated by cytotoxic $\mathrm{T}$ cells or humoral responses at the mucosal level have been demonstrated in exposed seronegative individuals (Mazzoli et al. 1997), indicating that acquired immunity might be the mechanism responsible to control the infection in these individuals. The relative importance of these mechanisms in populations with different modes of exposure or genetic background need to be elucidated

\section{REFERENCES}

Berger EA, Murphy PM, Farber JM 1999. Chemokine receptors as HIV-1 coreceptors: roles in viral entry, tropism and disease. Annu Rev Immunol 17: 657700.

Bernard N, Yannakis CM, Lee JS, Tsoukas CM 1999. Human immunodeficiency virus (HIV) specific cytotoxic T lymphocyte activity in HIV-exposed seronegative persons. J Infect Dis 179: 538-547.

Biti R, French R, Young J, Bennetts B, Stewart G 1997. HIV-1 infection in an individual homozygous for the CCR5 deletion allele. Nature Medicine 3: 252253.

Bravo ML, Valenzuela CY, Arcos-Burgos OM 1996. Polymorphism and phyletic relationships of the Paisa community from Antioquia (Colombia). Gene Geography 10: 11-17.

Dean M, Carrington M, Winkler C, Huttley G, Smith M, Allikmets R, Goedert J, Buchbinder SP, Vittinghoff E, Gomperts E, Donfield S, Vlahov D, Kaslow R, Saah A, Rinaldo C, Detels R 1996. Genetic restriction of HIV-1 infection and progression to AIDS by a deletion allele of the CCR5 structural gene. Science 273: 1856-1862.

Deng H, Liu R, Ellmeier W, Choe S, Unutmaz D, Burkhart M, Di Marzio P, Marmon S, Sutton RE, Hill M, Davis C, Peiper S, Schall TJ, Littman DR, Landau N 1996. Identification of a major co-receptor for primary isolates of HIV-1. Nature 381: 661-
666.

Feng Y, Broder CC, Kennedy PE, Berger EA 1996. HIV1 entry cofactor: functional cDNA cloning of a seven-transmembrane, G-coupled receptor. Science 272: 872-877.

Hoffman TL, MacGregor RR, Burger H, Mick R, Doms RW, Collman RG 1997. CCR5 genotypes in sexually active couples discordant for human immunodeficiency virus type 1 infectious status. J Infect Dis 176: 1093-1096.

Huang Y, Paxton WA, Wolinsky SM, Neumann AU, Zhang L, He T, Kang S, Ceradini D, Jin Z, Yazdanbakhsh K, Kunstman K, Erickson D, Dragon E, Landau NR, Phair J, Ho DD, Koup RA 1996. The role of a mutant CCR5 allele in HIV-1 transmission and disease progression. Nature Medicine 2: 1240-1243.

Liu R, Paxton WA, Choe S, Ceradini D, Martin SR, Horuk R, MacDonald ME, Stuhlmann H, Koup RA, Landau NR 1996. Homozygous defect in HIV-1 coreceptor accounts for resistence of some multiply-exposed individuals to HIV-1 infection. Cell 86 : 367- 377.

Magierowska M, Lepage V, Boubnova L, Carcassi C, De Juan D, Djoujah S, El Chenawi F, Grunnet N, Halle L, Ivanova R, Jungerman M, Naumovaa E, Petrany G, Sonnerborg A, Stavropoulos C, Thorsby E, Vu-Trieu A, Debre P, Theodorou I, Cgarron D 1998. Distribution of the CCR5 gene 32 base pair deletion and SDF1-3' A variant in healthy individuals from different populations. Immunogenetics 48 : 417-419.

Martinson JJ, Chapman NH, Rees DC, Liu YT, Clegg JB 1997. Global distribution of the CCR5 gene 32basepair deletion. Nature Genetics 16:100-103.

Mazzoli S, Trabattoni D, Lo Caputo s, Piconi S, Ble C, Meacci F, Ruzzante S, Salvi A, Semplici F, Longhi R, Fusi ML, Tofani N, Biasin M, Villa ML, Mazzota F, Clerici M 1997. HIV-specific mucosal and cellular immunity in HIV-seronegative partners of HIVseropositive individuals. Nature Medicine 3: 12501257.

McNicholl JM, Smith DK, Qari SH, Hodge T 1997. Host genes and HIV: the role of the chemokine receptor gene CCR5 and its allele ( $\Delta 32 \mathrm{CCR} 5)$. Emerging Infectious Diseases 3: 261-271.

Michael NL, Chang G, Louie LG, Mascola JR, Dondero D, Birx DL, Sheppard HW 1997. The role of viral phenotype and CCR-5 gene defects in HIV-1 transmission and disease progression. Nat Med 3: 338340.

Paxton AW, Martin SR,Tse D, O'brien TR, Skurnick J, VanDevanter NL, Padian N, Braun JF, Kotler DP, Wolinsky SM, Koup RA 1996. Relative resistance to HIV-1 infection of CD4 lymphocytes from persons who remain uninfected despite multiple highrisk sexual exposures. Nat Med 2: 412- 417.

Samson M, Libert F, Doranz BJ, Rucker J, Liesnard C, Farber CM, Saragosti S, Lapouméroulie C, Cognaux J, Forceille C, Muyidermans G, Verhofstede C, Burtonboy G, Georges M, Imai T, Rana S, Yi Y, Smyth RJ, Collman RG, Doms RW, Vassart G, 
Parmentier M 1996. Resistence to HIV-1 infection in caucasian individuals bearing mutants alleles of the CCR-5 chemokine receptor gene. Nature 382: 722-725.

Smith MW, Dean M, Carrington M, Winkler C, Huttley GA, Lomb DA, Goedert JJ, O'Brien TR, Jacobson LP, Kaslow R, Buchbinder S, Vittinghoff E, Vlahov D, Hoots K, Hilgartner MW 1997. Contrasting genetic influence of CCR2 and CCR5 variants on HIV-
1 infection and disease progression. Science 277: 959-965.

Winkler C, Modi W, Smith MW, Honjo T, Tashiro K, Yabe D, Buchbinder S, Vittinghoff E, Goedert JJ, O'Brien TR, Jacobson LP, Detels R, Donfield S, Willoughby A, Gomperts E, Vlahov D, Phair J, O'Brien SJ 1998. Genetic restriction of AIDS pathogenesis by an SDF-1 chemokine gene variant. Science 279: 389-393. 